\title{
Messenger RNAs are recruited for nuclear export during transcription
}

\author{
Elissa P. Lei, Heike Krebber, ${ }^{1}$ and Pamela A. Silver ${ }^{2}$ \\ Department of Biological Chemistry and Molecular Pharmacology, Harvard Medical School and Dana-Farber Cancer \\ Institute, Boston, Massachusetts 02115, USA
}

\begin{abstract}
Following transcription and processing, eukaryotic mRNAs are exported from the nucleus to the cytoplasm for translation. Here we present evidence that mRNAs are targeted for nuclear export cotranscriptionally. Combined mutations in the Saccharomyces cerevisiae hnRNP Npl3 and TATA-binding protein (TBP) block mRNA export, implying that cotranscriptional recruitment of $\mathrm{Npl} 3$ is required for efficient export of mRNA. Furthermore, Npl3 can be found in a complex with RNA Pol II, indicating that Npl3 associates with the transcription machinery. Finally, $\mathrm{Npl} 3$ is recruited to genes in a transcription dependent manner as determined by chromatin immunoprecipitation. Another mRNA export factor, Yra1, also associates with chromatin cotranscriptionally but appears to be recruited at a later step. Taken together, our results suggest that export factors are recruited to the sites of transcription to promote efficient mRNA export.
\end{abstract}

[Key Words: Transcription; mRNA export; chromatin IP; RNA polymerase II; Npl3; Yra1]

Received February 28, 2001; revised version accepted May 8, 2001.

Compartmentalization of the eukaryotic cell necessitates the movement of macromolecules through the nuclear envelope. In particular, mRNAs must be transported from the site of transcription in the nucleus to the cytoplasm for translation to occur. Export of mRNAs requires processing, packaging by RNA-binding proteins, recognition by export factors, and translocation through the nuclear pore complex (NPC) into the cytoplasm.

mRNAs transcribed by RNA Pol II undergo rapid processing in the nucleus. Pre-mRNA processing steps include addition of a $5^{\prime}$ monomethyl cap, splicing of introns, and 3' cleavage and polyadenylation. 5' capping occurs on nascent transcripts soon after transcription initiation (Salditt-Georgieff et al. 1980; Jove and Manley 1984; Rasmussen and Lis 1993). Furthermore, capping enzyme is associated with Pol II and can be found associated with promoters of transcribed genes (Cho et al. 1997; McCracken et al. 1997; Komarnitsky et al. 2000; Schroeder et al. 2000). Additionally, the transcription machinery interacts with splicing and 3 ' cleavage and polyadenylation factors, suggesting that these events occur either cotranscriptionally or soon after transcription termination (Mortillaro et al. 1996; Yuryev et al. 1996; Dantonel et al. 1997). Coordination of mRNA processing events and transcription is thought to be primarily through Pol II and its carboxy-terminal domain (CTD) in a manner that can be dependent on the state of CTD phosphorylation (for review, see Hirose and Manley 2000).

${ }^{1}$ Present address: Philipps-University Marburg, Institute for Molecular Biology and Tumor Research (IMT), 35037 Marburg, Germany. ${ }^{2}$ Corresponding author.

E-MAIL pamela_silver@dfci.harvard.edu; FAX (617) 632-5103.

Article and publication are at http://www.genesdev.org/cgi/doi/10.1101/ gad.892401.
In the nucleus, hnRNPs and other RNA-binding proteins package mRNAs into ribonucleoprotein particles (RNPs), and a subset of these proteins remain in the nucleus whereas others accompany the RNP into the cytoplasm, dissociate, and move back into the nucleus for further rounds of export. In the visually tractable Chironomus tentans, it is possible to study the very large (35-40 kb) Balbiani ring (BR) RNA throughout its various maturation stages, including transcription, nuclear export, and translation. Previous immunoelectron microscopy studies showed that the hnRNPs hrp36, hrp45, and hrp23 associate with the BR particle during its transcription (Alzhanova-Ericsson et al. 1996; Visa et al. 1996a; Sun et al. 1998). hrp45 and hrp23 dissociate from the BR particle at the nuclear pore whereas hrp36 can accompany the mRNP into the cytoplasm and remain associated during translation. Furthermore, CBP20, which together with CBP80 forms the mRNA cap-binding complex, was also shown to associate with the nascent BR particle (Visa et al. 1996b).

Recent studies have suggested that mechanisms exist to mark mRNAs as fully processed and export competent. In metazoans, splicing can enhance mRNA export (Luo and Reed 1999). The splicing machinery deposits a complex of proteins that mark exon-exon boundaries, and two members of this complex, Aly/REF and Y14, have been suggested to act as markers of spliced and export-competent RNPs (Kataoka et al. 2000; Le Hir et al. 2000; Zhou et al. 2000). Although it remains to be seen whether these proteins directly mediate the export process, both Aly and Y14 shuttle between the nucleus and cytoplasm, and the yeast homolog of Aly, Yral, is essential for mRNA export (Sträßer and Hurt 2000; Zhou et al. 2000). 
Recognition of the RNP for export may be mediated by a number of factors. A strong candidate for a metazoan mRNA export receptor is TAP, which binds and exports the constitutive transport element (CTE)-containing RNA produced by simian type D retroviruses (Gruter et al. 1998; Kang and Cullen 1999). Its yeast homolog, Mex67, along with the small protein Mtr2, is essential for mRNA export (Kadowaki et al. 1994; Santos-Rosa et al. 1998). Both TAP and Mex67 bind mRNA and contact components of the NPC (Katahira et al. 1999; Bachi et al. 2000; Sträßer et al. 2000).

Translocation of RNPs through the NPC undoubtedly requires the action of multiple nucleoporins as various mutations in nucleoporin genes result in blocked mRNA export (for review, see Fabre and Hurt 1997). The actual translocation process may be aided by the action of the ATP-dependent RNA helicase Dbp5/Rat8 and associated protein Gle1, which localize to the cytoplasmic side of the NPC and specifically contact Nup159 (Snay-Hodge et al. 1998; Hodge et al. 1999; Strahm et al. 1999). It has long been postulated and only recently shown that a helicase is able to remodel an RNA-protein complex, and this activity may serve as the mechanism for unwinding and translocating RNPs as well as releasing nonshuttling proteins from the mRNA at the NPC (Jankowsky et al. 2001). In summary, multiple factors are implicated in the translocation step of mRNA export.

Npl3 (also termed Mtr13/Mts1/Nab1/Nop3), a shuttling hnRNP that contains two RNA-recognition motifs (RRMs) and an RS-like domain, is a major mRNA-binding protein in S. cerevisiae (Wilson et al. 1994). Mutations in Npl3 cause nuclear accumulation of mRNA, indicating a role for $\mathrm{Npl3}$ in the mRNA export process (Singleton et al. 1995; Lee et al. 1996). It has been postulated that along with other proteins, Npl3 packages pre-mRNA into an export-competent RNP and escorts it through the NPC (Lee et al. 1996; Shen et al. 1998). On arrival in the cytoplasm, Npl3 dissociates from mRNA and is transported back into the nucleus by the importin Mtr10 to allow further rounds of mRNA export (Pemberton et al. 1997; Senger et al. 1998). These characteristics of Npl3 make it an attractive paradigm for the function of hnRNPs with respect to nuclear export of mRNA.

In an effort to study Npl3 and mRNA export, we found that combined mutations in $\mathrm{Npl3}$ and TATA-binding protein (TBP) block mRNA export. Moreover, we show that Npl3 is found in a complex with RNA Pol II and is associated with genes in a transcription dependent manner. Furthermore, the mRNA export factor Yral also associates with transcribed chromatin but is recruited at a later step than Npl3. These results suggest that cotranscriptional recruitment of mRNA export factors may be critical for proper mRNA export.

\section{Results}

A screen for Np13 export factors identifies SPT15, which encodes TATA-binding protein

The export of Npl3 is intimately tied to that of mRNA; therefore, we postulated that studying Npl3 export would yield information about general mRNA export. To identify factors important for $\mathrm{Npl3}$ and mRNA nuclear export, a mutant npl3-27 was employed. Npl3-27 contains a single point mutation (E409K), and cells bearing this mutation are viable at all temperatures (Lee et al. 1996). However, the cellular distribution of Npl3-27 is altered with respect to wild-type Npl3. At steady state, wild-type Npl3 localizes predominantly to the nucleus (Fig. 1A, panels a-c) whereas the Npl3-27 mutant localizes to both the nucleus and cytoplasm at $37^{\circ} \mathrm{C}$ (Fig. $1 \mathrm{~A}$, panels $\mathrm{d}-\mathrm{f}$ ) as detected by indirect immunofluorescence using polyclonal $\alpha$-Npl3 antibodies (Bossie et al. 1992; Krebber et al. 1999). Npl3-27 appears to have a slowed rate of import because overexpression of the Npl3 import receptor gene, MTR10, results in restoration of Npl3-27 nuclear localization (Krebber et al. 1999). The E409K mutation maps to the region that is important for $\mathrm{Npl} 3$ nuclear localization, further supporting this explanation (Flach et al. 1994). It has been shown previously that mutations that cause mRNA export defects also cause nuclear accumulation of Npl3-27, indicating that Npl327 export is subject to the same requirements as mRNA export (Krebber et al. 1999). As seen by in situ hybridization using an oligo $(\mathrm{dT})_{50}$ probe, wild-type (Fig. 1B, panels a-c) and npl3-27 cells (Fig. 1B, panels d-f) display the same distribution of mRNA throughout the nucleus and cytoplasm (Amberg et al. 1992; Krebber et al. 1999). Therefore, Npl3-27 is functional for mRNA export despite its altered cellular localization. Furthermore, as has been shown with similar mutant forms of Npl3, Npl3-27 is capable of binding mRNA in vivo at $25^{\circ} \mathrm{C}$ and $37^{\circ} \mathrm{C}$ as determined by UV-crosslinking (data not shown; Gilbert et al. 2001). The cellular level of Npl3-27 is equivalent to that of wild type at both $25^{\circ} \mathrm{C}$ and $37^{\circ} \mathrm{C}$ (Krebber et al. 1999).

Taking advantage of the altered localization but wildtype activity of Npl3-27, we performed a genetic screen to identify genes required for Npl3-27 export. A temperature-sensitive $\left(t s^{-}\right)$library from the npl3-27 strain was created by EMS mutagenesis and was screened for nuclear accumulation of Npl3-27. An intergenic mutation (F183I) in an RRM domain of NPL3 was obtained that also causes an mRNA export defect. Moreover, a mutation in the mRNA export factor MTR2 was also found (data not shown). Identification of these two mutations verified that this screen is capable of identifying genes that affect Npl3 and mRNA export. This screen also identified a mutation in SPT15, which encodes the transcription initiation factor TBP. Sequencing of this mutant revealed that the mutation is identical to a previously reported $t s^{-}$spt15 mutant termed spt15-ts1 (Cormack and Struhl 1992). This mutant displays a nuclear accumulation of Npl3-27 at the nonpermissive temperature of $37^{\circ} \mathrm{C}$ indicating a block of Npl3-27 export (Fig. 1A, panels g-i). Levels of Npl3-27 are not affected (data not shown).

NPL3 and SPT15 genetically interact to promote mRNA export

Unexpectedly, in addition to nuclear accumulation of Npl3-27, spt15-ts1 npl3-27 cells display an mRNA ex- 
A

npl3-27

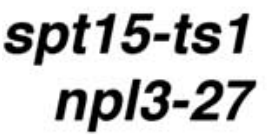

spt15-ts1

B

npl3-27

\section{spt15-ts 1 npl3-27}

\section{spt15-ts1}

$\alpha$ Npl3 DAPI
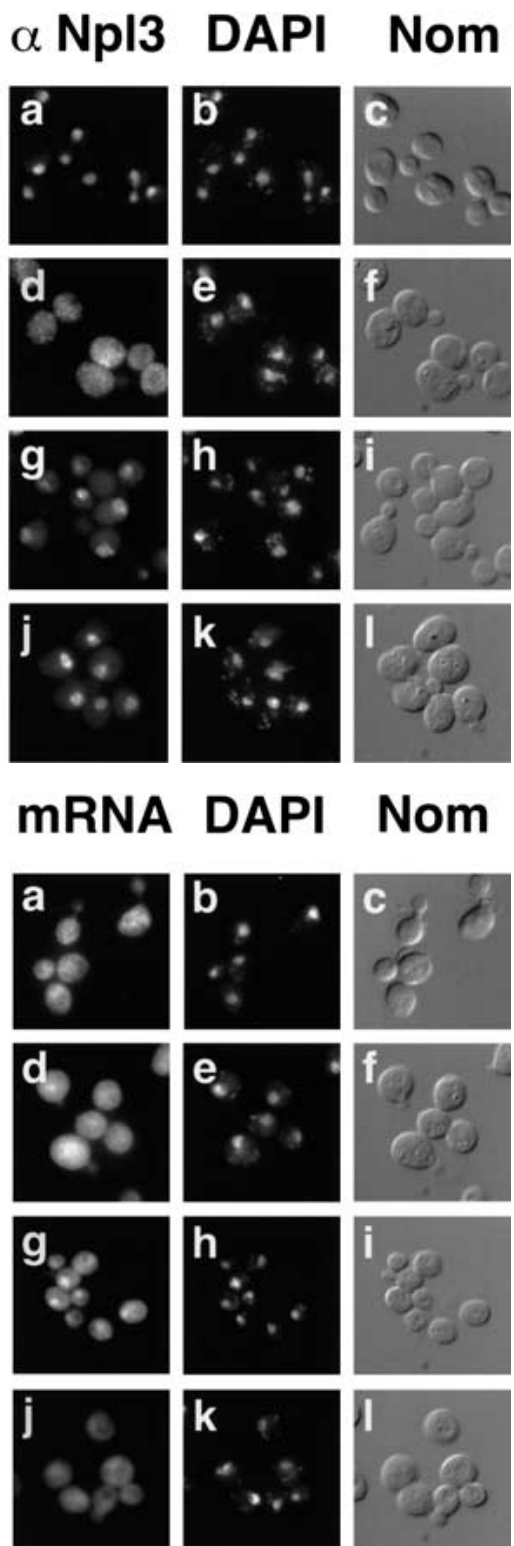

Figure 1. spt15-ts1 npl3-27 cells are slowed for Npl3-27 export and display a synthetic mRNA export defect. $(A)$ Localization of Npl3 or Npl3-27 in wild type (PSY580, $a-c$ ), npl3-27 (PSY1031, $d-f$ ), spt15-ts1 npl3-27 (PSY1698, g-i) and spt15-ts1 cells (PSY1702, j-1). Cells were shifted to $37^{\circ} \mathrm{C}$ for $1 \mathrm{~h}$. Indirect immunofluorescence with polyclonal antibodies to Npl3 (left), DAPI (center), and Nomarski images (right) are shown. (B) Localization of poly $(\mathrm{A})^{+} \mathrm{RNA}$ in wild type $(a-c), n p 13-27(d-f)$, spt15-ts1 $n p 13-27(g-i)$, and spt15-ts 1 cells $(j-1)$. Cells were shifted to $37^{\circ} \mathrm{C}$ for $1 \mathrm{~h}$. in situ hybridization with an oligo $(\mathrm{dT})_{50}$ probe (left), DAPI (center), and Nomarski images (right) are shown.

port defect. Poly $(\mathrm{A})^{+}$RNA accumulates in the nucleus of spt15-ts1 npl3-27 cells shifted to $37^{\circ} \mathrm{C}$ for $1 \mathrm{~h}$ (Fig. 1B, panels g-i). Neither the single spt15-ts1 mutation (Fig. 1B, panels $j-1$ ) nor the npl3-27 mutation (Fig.1B, panels $\mathrm{d}-\mathrm{f}$ ) in isolation cause nuclear accumulation of mRNA. Consistent with a defect in transcription at $37^{\circ} \mathrm{C}$, spt15ts 1 cells display a lower intensity poly $(\mathrm{A})^{+}$RNA signal distributed throughout the cells relative to wild type (Fig. 1B, panels j-1). Double mutant spt15-ts1 npl3-27 cells (Fig. 1B, panels g-i) display a nuclear RNA signal that is of considerably higher intensity than that of spt15-ts1 cells. One explanation is that blocked export and subsequent concentration of mRNA in the nucleus causes a brighter signal. Another possibility is that npl327 decreases the rate of mRNA degradation in the nucleus, resulting in an increase of the overall poly $(\mathrm{A})^{+}$ RNA signal and an apparent accumulation in the nucleus.

To verify that spt15-ts1 npl3-27 cells exhibit a true decrease in mRNA export and not a defect in mRNA stability, we harvested total RNA from wild-type, spt15ts1, spt15-ts1 npl3-27, and npl3-27 cells and determined the amount of steady state poly $(\mathrm{A})^{+}$RNA in strains grown at $25^{\circ} \mathrm{C}$ or shifted to $37^{\circ} \mathrm{C}$ for $1 \mathrm{~h}$. The amount of poly $(\mathrm{A})^{+}$RNA was determined by hybridization to a radiolabeled poly dT probe. Levels of $18 \mathrm{~S}$ rRNA were verified to be constant among samples (data not shown). Single spt15-ts1 mutant cells (Fig. 2A, lanes 5,6) and double spt15-ts1 np13-27 cells (Fig. 2A, lanes 3,4) showed an identical decrease in poly $(\mathrm{A})^{+}$RNA after the shift to $37^{\circ} \mathrm{C}$. The poly $(\mathrm{A})^{+} \mathrm{RNA}$ level in single npl3-27 mutant cells (Fig. 2A, lanes 7,8) matched that of wild type (Fig $2 \mathrm{~A}$, lanes 1,2 ), indicating that $n p 13-27$ has no effect on total mRNA levels. To rule out the effects of poly(A) tail length, Northern analysis was performed on the ACT1 transcript, and these results mirrored those of the poly $(\mathrm{A})^{+}$RNA slot blot. Wild-type ACT1 levels (Fig. 2B, lanes 1,2) matched those of $n p 13-27$ cells (Fig. $2 \mathrm{~B}$, lanes 7,8), and spt15-ts1 npl3-27 ACT1 levels (Fig. 2B, lanes

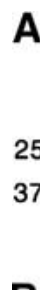

B
Figure 2. $n p 13-27$ has no effect on total mRNA levels. $(A)$ Slot blot hybridization of total poly $(\mathrm{A})^{+}$RNA of wild type (lanes 1-2, PSY580 and 603), spt15-ts1 npl3-27 (lanes 3-4, PSY1698 and 1699), spt15-ts1 (lanes 5-6, PSY1702 and 1703), and npl3-27 cells (lanes 7-8, PSY1031 and 1032). Cells were grown to $\log$ phase at $25^{\circ} \mathrm{C}$, cultures were split, one half was shifted to $37^{\circ} \mathrm{C}$ for $1 \mathrm{~h}$, and total RNA was isolated. Two $\mu \mathrm{g}$ of total RNA was probed with a ${ }^{32} \mathrm{P}$-labeled poly dT probe. $(B) A C T 1$ Northern of wild type (lanes 1-2), spt15-ts1 npl3-27 (lanes 3-4), spt15-ts1 (lanes 5-6), and npl3-27 cells (lanes 7-8). Cells were grown to log phase at $25^{\circ} \mathrm{C}$, cultures were split, one half was shifted to $37^{\circ} \mathrm{C}$ for $1 \mathrm{~h}$, and total RNA was isolated. Fifteen $\mu \mathrm{g}$ of total RNA separated by agarose gel electrophoresis was probed with a ${ }^{32} \mathrm{P}$ labeled $A C T 1$ probe. 
3,4) matched those of spt15-ts1 cells (Fig. 2B, lanes 5,6) after a shift to $37^{\circ} \mathrm{C}$ for $1 \mathrm{~h}$. Differences in reduction of transcription levels seen in the spt15-ts1 and spt15-ts1 npl3-27 cells between the two assays are likely attributable to the higher stability of the ACT1 transcript relative to total mRNA. Therefore, nuclear mRNA accumulation in spt15-ts1 npl3-27 cells results from decreased mRNA export and not altered mRNA stabilization.

These results indicate that NPL3 and SPT15 genetically interact, ensuring proper mRNA export. Furthermore, npl3-27 exerts a dominant effect on spt15-ts1 cells and not wild-type cells in that expression of exogenous npl3-27 over endogenous wild-type NPL3 causes an mRNA export defect in spt15-ts1 cells. We tested other $t s^{-}$alleles of spt15 (spt15-328 and spt15-341; Arndt et al. 1995) in combination with npl3-27 and found that these alleles also displayed nuclear accumulation of Npl3-27 and mRNA. To determine the specificity of this genetic interaction, we examined strains mutated for RNA Pol II

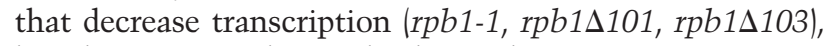
but these strains do not display Npl3-27 or mRNA export defects (data not shown). Therefore, there is a specific genetic interaction between SPT15 and NPL3, which suggests interplay between the mRNA transcription and nuclear export machinery.

\section{Npl3 and RNA Pol II exist in a complex}

The genetic interaction between NPL3 and SPT15 suggested that Npl3 and TBP or some component of the transcription machinery may interact physically. Therefore, we performed $\alpha$-Npl3 immunoprecipitation experiments to isolate endogenous $\mathrm{Npl} 3$ and bound proteins from yeast cell extracts. We were unable to detect TBP in a complex with Npl3 (data not shown). However, we found that a small amount of RNA Pol II coimmunoprecipitates with $\alpha$-Npl3 antibodies (Fig. 3, lane 2). Furthermore, we found that this association is not RNA-dependent as Pol II is still found associated with Npl3 after incubation with RNase A (Fig. 3, cf. lanes 2 and 3). These results indicate that Npl3 is associated with the transcription machinery and may be recruited to transcribing genes by RNA Pol II.

Np13 is associated with the chromatin of genes in a transcription-dependent manner

To determine whether Npl3 is localized in the vicinity of transcribed genes, we tested whether $\mathrm{Npl} 3$ is recruited to mRNAs cotranscriptionally by the method of chromatin immunoprecipitation (Orlando et al. 1997). We chose to analyze the promoter and coding region of the constitutively and highly transcribed PMA1 gene as well as a nontranscribed region devoid of open reading frames (ORFs) on a different chromosome. Chromatin of an average size of $200 \mathrm{bp}$ was prepared from wild-type cells, and as a positive control, TBP was immunoprecipitated using polyclonal $\alpha$-TBP antibodies. Similarly, Npl3 was immunoprecipitated using polyclonal $\alpha-\mathrm{Npl3}$ antibod-

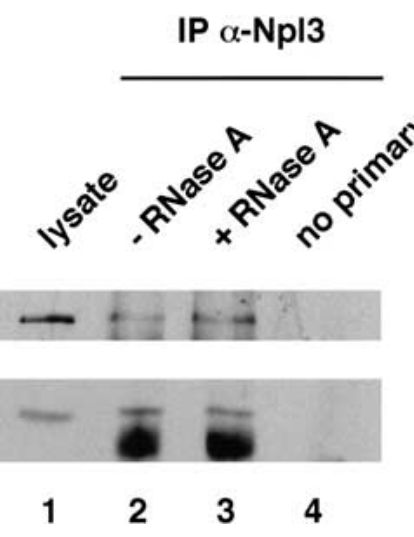

Figure 3. Npl3 and RNA Pol II form a complex that is not dependent on RNA. Npl3 from cell lysates is immunoprecipitated with $\alpha-\mathrm{Npl3}$ antibodies (bottom). Heavy chain of the primary antibody is denoted with an asterisk. RNA Pol II is coimmunoprecipitated with Npl3 (top). Total cell lysate is loaded (lane 1). After binding and washing, samples were treated with $50 \mu \mathrm{g} / \mathrm{mL}$ RNase A in wash buffer (lane 3) or wash buffer alone (lane 2) and incubated at RT for $20 \mathrm{~min}$. Samples were washed once and raised in sample loading buffer, run on a 7\% SDSPAGE gel and Western blotted with $\alpha$-Npl3 antibodies or 8 WG16 against Pol II CTD. No primary samples were mock IPs lacking primary antibody (lane 4). Blots shown are from two different gels from the same experiment. Approximately $20 \%$ of $\mathrm{Npl} 3$ and $0.02 \%$ of Pol II were immunoprecipitated from the lysate.

ies. The amount of DNA associated with each protein was determined by performing quantitative PCR using primer sets spanning the indicated regions (Fig. 4A). For illustrative purposes, PCR products from a single dilution of input and a single dilution of each immunoprecipitate that are known to be in the linear range of PCR are shown. In accordance with previous studies, $\alpha$-TBP antibodies preferentially immunoprecipitate promoter DNA (Fig. 4B, center panel, lane 1) in comparison to DNA spanning the coding sequence (Fig. $4 \mathrm{~B}$, center panel, lanes 2,3) and intergenic region (Fig. 4B, center panel, lane 4; Komarnitsky et al. 2000; Kuras and Struhl 1999).

Npl3 immunoprecipitates modest levels of the PMA1 promoter region (Fig. 4B, right panel, lane 1) and high levels of ORF DNA (Fig. 4B, right panel, lanes 2,3) in comparison with the intergenic region (Fig. $4 \mathrm{~B}$, right panel, lane 4). For each primer set, percentages of input DNA present in the $\alpha$-Npl3 immunoprecipitate were graphed with quantitation error for a single experiment (Fig. 4C). Values were normalized by dividing the percentage obtained for each primer set by the percentage of intergenic region (Fig. 4C, bottom). Approximately 1.5fold more promoter DNA (Fig. 4C, bar 1) and 12- to 17 fold more coding sequence (Fig. 4C, bars 2,3) immunoprecipitate with $\alpha$-Npl3 antibodies compared to the intergenic region (Fig. 4C, bar 4), indicating that Npl3 is associated with chromatin of a transcribing gene. Similar results were obtained using a monoclonal antibody to Npl3 (1E4) and $\alpha$-myc antibodies to a myc epitope-tagged version of Npl3. Background signal $(<0.047 \%)$ was ob- 


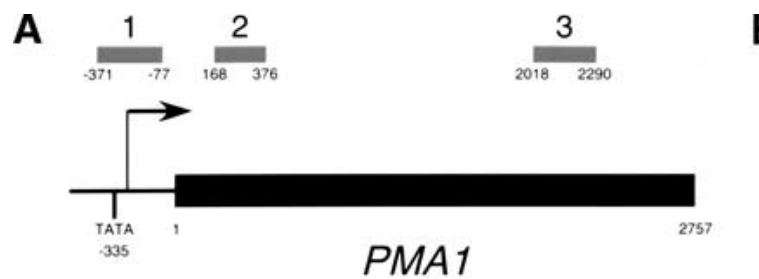

$4=$ intergenic region

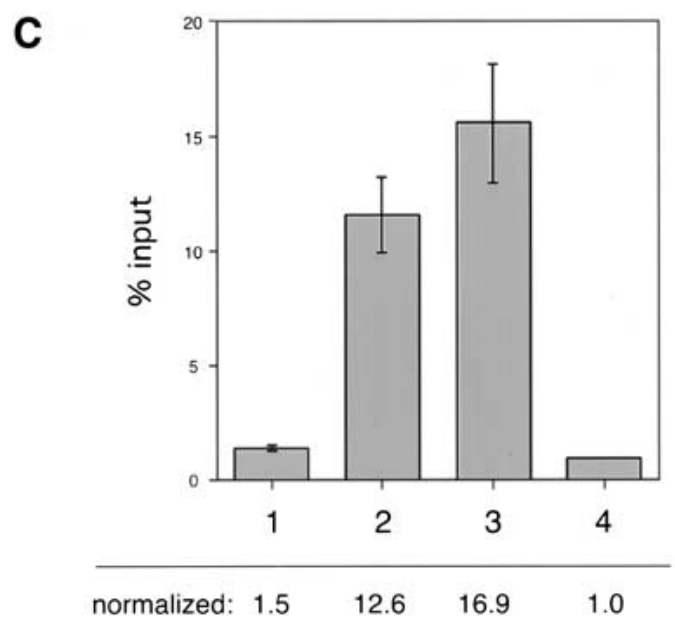

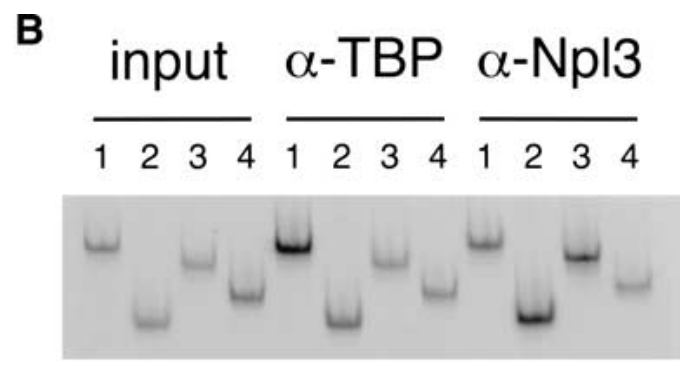

D

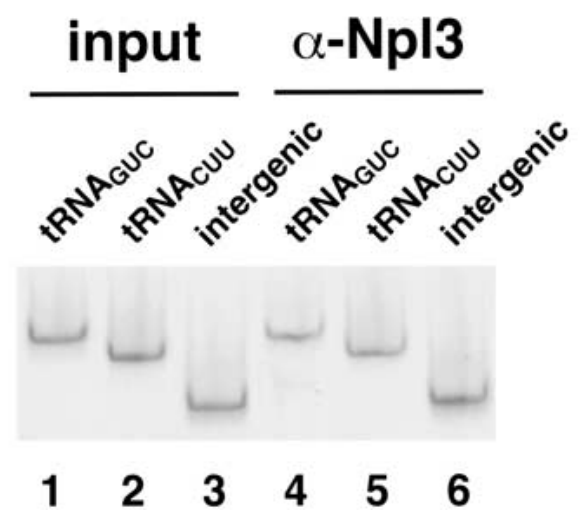

Figure 4. Npl3 crosslinks to the promoter and coding sequence of the constitutively expressed Pol II transcribed $P M A 1$ gene. $(A)$ Diagram of $P M A 1$. Primer set 1 spans the promoter including the TATA box. Primer set 2 spans the $5^{\prime}$ region of the coding sequence. Primer set 3 spans the $3^{\prime}$ region of the coding sequence. (ATG $=+1$ ). Primer set 4 spans a nontranscribed intergenic region. $(B)$ Npl3 immunoprecipitates promoter and coding sequence of PMA1. Quantitative PCR of input (left), $\alpha$-TBP immunoprecipitate (center) and $\alpha$-Npl3 immunoprecipitate (right) using primers sets 1-4 spanning regions as indicated in $A$. PCR products were separated on an $8 \%$ TBE polyacrylamide gel. Single dilutions of each template are shown and are in the linear range of PCR (data not shown). (C) Quantitation of $\alpha-\mathrm{Npl} 3$ immunoprecipitated material. Raw values are expressed in graphical form as percentage of input. Error bars $>0.1$ are shown for a single experiment. Normalized values were obtained by dividing the percentage obtained for each primer set by the percentage obtained of primer 4 (bottom). (D) Npl3 does not associate with Pol III transcribed genes. Quantitative PCR of input (lanes 1-3) and Npl3 immunoprecipitate (lanes 4-6) of DNA spanning the tRNA $\mathrm{GUC}_{\text {gene }}$ (lanes 1,4), tRNA $\mathrm{CUU}_{\mathrm{Cu}}$ gene (lanes 2,5), and intergenic region (lanes 3,6).

tained with $\alpha$-myc antibodies in a strain in which $\mathrm{Npl3}$ was not tagged with myc (data not shown). To examine the specificity of $\mathrm{Npl} 3$ chromatin association with Pol II transcribed genes, we analyzed two Pol III transcribed tRNA genes (Fig. 4D). In comparison to input (Fig. 4D, lanes 1-3), Npl3 does not associate with regions contain-

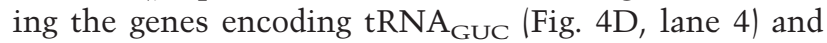
tRNA $_{\mathrm{CUU}}$ (Fig. 4D, lane 5) or the intergenic region (Fig. 4D, lane 6). These results show that Npl3 associates specifically with Pol II transcribed genes.

To determine if the association of Npl3 with genes is dependent on transcription, we analyzed the highly transcribed galactose inducible GAL10 gene using primer sets spanning the promoter and coding sequence (Fig. 5A). Chromatin was prepared from cells grown in noninducing glucose-containing media as well as cells grown in inducing galactose-containing media. In cells grown in glucose, GAL10 expression is repressed, and $\alpha$-TBP antibodies immunoprecipitate background levels of DNA (Fig. 5B, center panel, lanes 1-5). With galactose induction, $\alpha$-TBP antibodies immunoprecipitate a sig- nificant level of upstream activating sequence (UAS) DNA (Fig. 5B, center panel, lane 1) and DNA directly downstream of the TATA-box and $5^{\prime}$ coding sequence (Fig. 5B, center panel, lane 2) but not DNA well into the coding region of GAL10 (Fig. 5B, center panel, lanes 3,4) or the intergenic region (Fig. 5B, center panel, lane 5).

$\alpha$-Npl3 antibodies immunoprecipitate background levels of DNA from cells grown in glucose. Under transcription-inducing conditions, $\alpha$-Npl3 antibodies immunoprecipitate a significant amount of GAL10 UAS DNA (Fig. 5B, right panel, lane 1) and a much greater amount of DNA corresponding to coding sequence (Fig. 5B, right panel, lanes 2-4). For each primer set, percentages of input DNA present in the $\alpha$-Npl3 immunoprecipitate after galactose induction (Fig. 5C, gray bars) and noninducing conditions (Fig. 5C, white bars), were graphed with quantitation error for a single experiment (Fig. 5C). Values were normalized by dividing the percentage obtained for each primer set by the percentage of intergenic region. The ratio of these normalized values of galactose to glucose are indicated (Fig. 5C, bottom). Approximately a 
Lei et al.

A

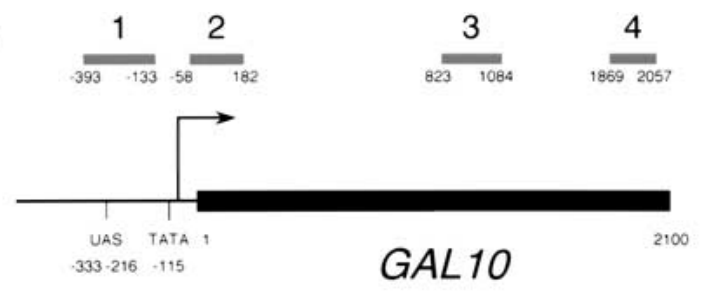

$5=$ intergenic region

B

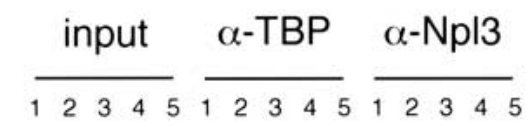

Glu

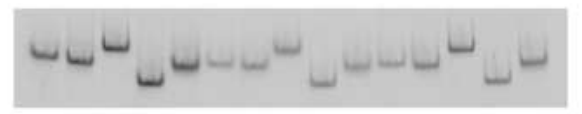

Gal

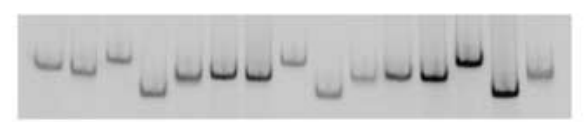

C

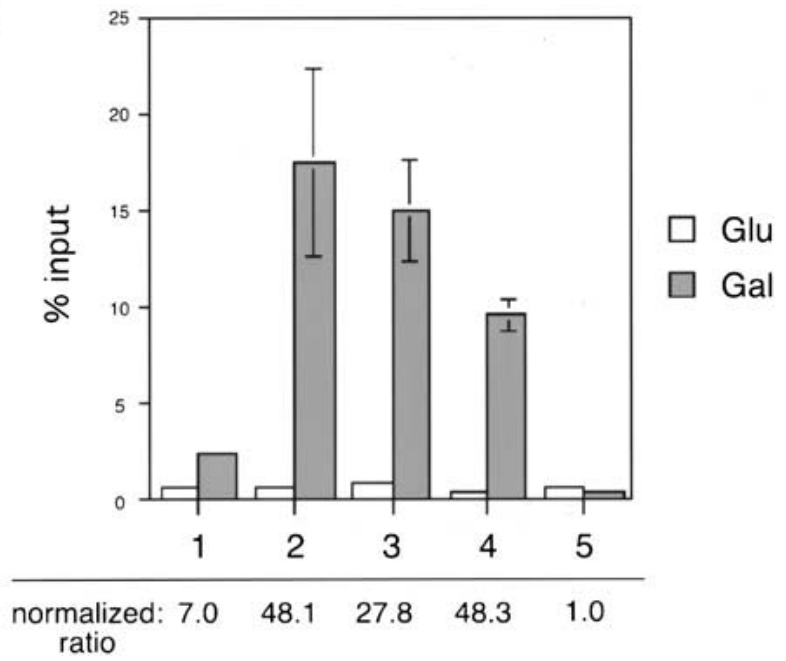

Figure 5. Npl3 crosslinks to the promoter and coding sequence of GAL10 in a transcription dependent manner. (A) Diagram of GAL10. Primer set 1 spans the upstream activating sequence. Primer set 2 spans the promoter and 5' coding sequence. Primer set 3 spans the middle of the coding sequence. Primer set 4 spans the $3^{\prime}$ coding sequence. Primer set 5 spans a nontranscribed intergenic region. (B) $\mathrm{Npl} 3$ immunoprecipitates promoter and coding sequence of GAL1O under inducing conditions. Quantitative PCR of input (left), $\alpha$-TBP immunoprecipitate (center), and $\alpha-\mathrm{Npl3}$ immunoprecipitate (right) using primers sets 1-5 spanning regions as indicated in $A$. Cells were grown in glucose (top) or galactose (bottom). (C) Quantitation of $\alpha-\mathrm{Npl} 3$ immunoprecipitated material. Raw values are expressed for cells grown in glucose (white) and galactose (gray) in graphi$\mathrm{cal}$ form as a percentage of input. Error bars $>0.3$ are shown for one experiment. Normalized ratio values were obtained by dividing galactose values by glucose values for each primer set and normalizing to primer set 5 .

7-fold increase of UAS DNA (Fig. 5C, bar 1) and 30- to 50-fold increase of ORF DNA (Fig. 5C, bars 2-4) was immunoprecipitated with $\alpha-\mathrm{Npl} 3$ antibodies after galactose induction compared to noninducing conditions, in- dicating that Npl3 is associated with GAL10 in a transcription dependent manner.

\section{Yra1 associates with chromatin at a later step} of transcription

To determine whether cotranscriptional recruitment of mRNA export factors is a general phenomenon, we examined whether Yral associates with genes by chromatin immunoprecipitation. Chromatin was prepared from cells containing a myc-epitope tagged version of Yral (K. Straesser and E.C. Hurt, unpubl.), and Yral-myc was immunoprecipitated with $\alpha$-myc antibodies. Quantitative PCR was performed for regions of PMA1 as described in Figure 5A. In comparison to the intergenic reference primer (Fig. 6A, bar 4), Yral-myc does not associate with PMA1 promoter DNA (Fig. 6A, bar 1) but does so modestly with PMA1 5' coding sequence (Fig. 6A, bar 2) and
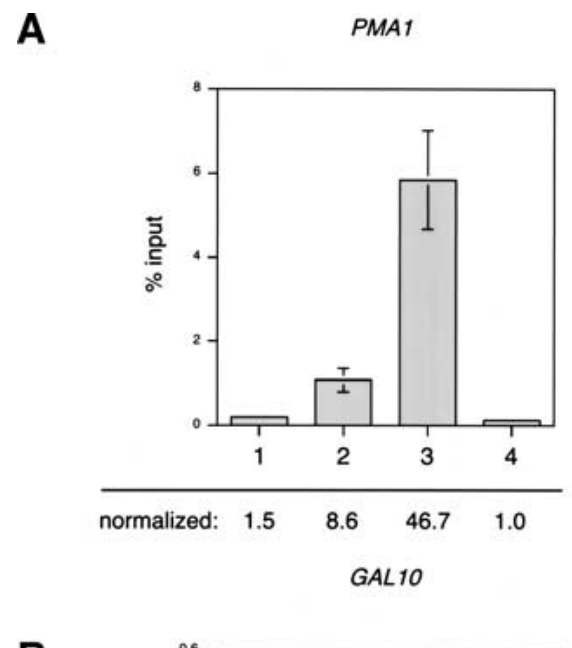

B

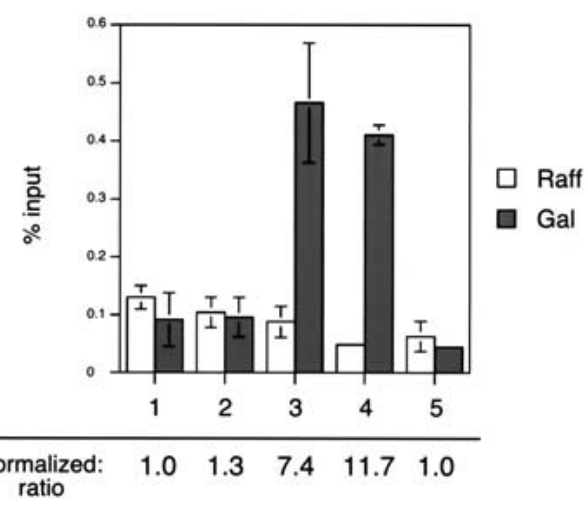

Figure 6. Yral is associated with the $3^{\prime}$ end of genes in a transcription dependent manner. (A) Quantitation of Yral-myc association with the PMA1 promoter (bar 1), 5' coding sequence (bar 2), and 3' coding sequence (bar 3) and intergenic region (bar 4). Values normalized to intergenic region are shown (bottom). (B) Quantitation of Yra1-myc association with the GAL10 UAS (bars 1), 5' coding sequence (bars 2), middle coding sequence (bars 3), 3' coding sequence (bars 4), and intergenic region (bars $5)$ in cells grown in raffinose (white) and galactose (gray). Normalized ratio values are shown (bottom). 
strongly with 3' coding sequence (Fig. 6A, bar 3). Values were normalized to the intergenic region, indicating an eightfold increase of $5^{\prime}$ coding sequence and a 40 -fold increase of 3' coding sequence (Fig. 6A, bottom). Therefore, Yral associates with the coding sequence of a transcribing gene. Furthermore, Yral association is biased toward the $3^{\prime}$ of PMA1 in contrast to Npl3, which associates strongly at the $5^{\prime}$ end of PMA1 (Fig. 4).

To assess transcriptional dependence of Yral association with genes, we examined the GAL10 inducible gene (Fig. 5A) in chromatin prepared from cells grown in noninducing raffinose-containing media or inducing galactose-containing media. Under noninducing conditions (Fig. 6B, white bars), Yra1-myc did not immunoprecipitate a significant amount of GAL10 sequence (Fig. 6B, bars 1-4) compared to the intergenic reference primer (Fig. 6B, bar 5). However, under inducing conditions (Fig. $6 \mathrm{~B}$, gray bars), Yra1-myc preferentially associated with the middle and $3^{\prime}$ regions of GAL10 coding sequence (Fig. 6B, bars 3,4) and not UAS or 5 ' sequences (Fig. 6B, bars 1,2 ). Normalized ratios were obtained by dividing percent input values obtained in galactose by values obtained in raffinose and show that there is a 10 -fold induction of association with GAL10 middle and 3' coding sequence (Fig. 6B, bottom). These results indicate that Yral associates with genes in a transcription-dependent manner. Furthermore, Yral binds preferentially to the $3^{\prime}$ ends of both PMA1 and GAL10 in contrast to Npl3, which binds strongly to the $5^{\prime}$ ends and throughout the coding sequence of both genes.

\section{Discussion}

hnRNP proteins are proposed to play essential roles in pre mRNA processing and nuclear export. The highly conserved process of mRNA export is perhaps best understood in the yeast $S$. cerevisiae where many factors have been defined, one of which is the major mRNAbinding protein Npl3. In an effort to understand how $\mathrm{Npl3}$ is involved in mRNA export, we designed a genetic screen to identify mutations that block Npl3 export, and we successfully identified known mRNA export factors. As a result of this screen, we also found that mutation of TBP could affect both Npl3 and mRNA export. Next, we showed that Npl3 exists in a complex with RNA Pol II and that $\mathrm{Npl3}$ association with genes is transcription dependent. Finally, we have shown that another mRNA export factor, Yra1, is also cotranscriptionally recruited at a later step of transcription. Taken together, these results suggest that the process of mRNA nuclear export begins at the level of transcription.

\section{SPT15 and NPL3 interact to promote mRNA export}

The mRNA that is produced in spt15-ts1 npl3-27 double mutant cells is not efficiently exported from the nucleus. One possibility is that reduced transcription levels give rise to this defect. In spt15-ts 1 cells, TBP is reduced in its ability to bind promoter DNA at the nonpermissive temperature, thereby compromising its role in transcription initiation and recruitment of the preinitiation complex to the promoter (Cormack and Struhl 1992). However, the reduced level of transcription cannot be the sole cause of the mRNA export defect because transcription levels are equally reduced in the spt15-ts1 single mutant and spt15-ts1 npl3-27 double mutant, and npl3-27 alone does not affect mRNA levels. Furthermore, when npl327 is combined with mutations in Pol II that reduce transcription levels, mRNA export is not affected. In addition, we found that Npl3-27 and mRNA export is also affected in two other spt15 ts $\mathrm{s}^{-}$mutants. Therefore, there is a specific genetic interaction between NPL3 and SPT15 to promote mRNA export that may not be entirely dependent on transcription levels.

Another possibility is that in spt15-ts1 npl3-27 cells, decreased activity of TBP combined with the smaller population of Npl3-27 in the nucleus causes an accumulation of export incompetent mRNAs. This hypothesis assumes that $n p 13-27$ is a loss-of-function mutation, and thus we would expect that expression of wild-type NPL3 would rescue the mRNA export defect of spt15-ts1 npl327 cells; however, we have found that this is not the case (E. Lei and P. Silver, unpubl.). Moreover, we have found that npl3-27 exerts a dominant effect over wild-type NPL3 in spt15-ts1 cells to cause an mRNA export defect. Therefore, npl3-27 does not appear to be a simple lossof-function mutation, suggesting that an alteration of Npl3-27 function with respect to wild type is important for the synthetic mRNA export defect when combined with spt15 mutations.

Although Npl3-27 clearly displays altered localization compared to wild type, the precise nature of the Npl3-27 mutant is unclear. The point mutation E309K lies in a region that contains the NLS. It has been proposed that $\mathrm{Npl3}$ binds to mRNA in the nucleus, remains associated throughout export, and releases from the RNA during reimport (Pemberton et al. 1997). Although the assay is not quantitative, our UV-crosslinking studies consistently reveal that a larger population of Npl3-27 than wild-type Npl3 may exist bound to mRNA. Therefore, cytoplasmic accumulation of Npl3-27 may be tied to an inability to release RNA as efficiently as wild type. Changes in the behavior of Npl3-27 with respect to RNA binding could affect many aspects of mRNA export such as loading of Npl3-27 onto the nascent transcript, packaging of the RNP, and interaction of the RNP with transport factors. We were unable to test the behavior of Npl3-27 by chromatin immunoprecipitation because of the inability to immunoprecipitate the mutant protein (data not shown). Further studies of Npl3-27 function will shed light on the intriguing genetic interaction between NPL3 and SPT15.

\section{Recruitment of Np13 to transcribing genes}

Our results show that $\mathrm{Npl3}$ is recruited to genes in a transcription-dependent manner. Promoter DNA found in the chromatin immunoprecipitations, albeit at lower levels than the coding region, suggest that the earliest step of Npl3 recruitment is at the site of transcription 
initiation. Although the method of chromatin immunoprecipitation has limited resolution, we were able to see differences between the footprints of Npl3 and Yra1, which associates strongly with the $3^{\prime}$ ends of coding sequences, suggesting that $\mathrm{Npl3}$ promoter association is significant. We predicted that there might be a physical interaction between $\mathrm{Npl} 3$ and some component of the transcription machinery. Although attempts to coimmunoprecipitate Npl3 with TBP and other transcription factors yielded negative results, we were able to detect an interaction of Npl3 with RNA Pol II, indicating that Npl3 physically interacts with the transcription machinery.

Pol II undergoes cycles of phosphorylation and dephosphorylation at its CTD, and this cycle coincides with Pol II activity (Hirose and Manley 2000). Pol II is hypophosphorylated while engaging in initiation and hyperphosphorylated during elongation. Furthermore, multiple elongation and mRNA processing factors are recruited by the Pol II CTD in a manner that is dependent on the state of CTD phosphorylation. We detected Pol II using an antibody that recognizes the unphosphorylated CTD (8WG16) and not with lower affinity antibodies directed to two different phosphorylation sites in the CTD (H14 and H5). Although elongating Pol II may be partially dephosphorylated in these experiments, these results are consistent with the possibility that $\mathrm{Npl3}$ is recruited by unphosphorylated Pol II in the preinitiation complex and transferred to the nascent RNA at the start of elongation (Fig. 7). Alternately, Npl3 may be recruited to elongating polymerase soon after transcription initiation and then transferred to RNA. Moreover, Npl3 may be further recruited by cooperative self-association or by the RNA itself.

To address whether RNA may be necessary for Npl3 recruitment, we performed chromatin immunoprecipitation after extensive RNase A treatment and obtained similar results as described previously, indicating that $\mathrm{Npl3}$ is not associated with chromatin entirely through RNA contacts (E. Lei and P. Silver, unpubl.). However, it should be noted that RNase A treatment cannot be performed before crosslinking; therefore, it is impossible to rule out that $\mathrm{Npl} 3$ association relies on contacts that are mediated by large RNA/protein complexes. Therefore, it remains a possibility that the growing nascent transcript further recruits Npl3. Future studies will determine how RNA, Pol II CTD phosphorylation, and other transcription factors affect $\mathrm{Npl3}$ recruitment.

\section{Another mRNA export factor, Yra1, is cotranscriptionally recruited}

The mRNA export factors Aly/REF in metazoans and Yral in yeast have been proposed to mark fully processed mRNAs for nuclear export (Luo and Reed 1999; Sträßer and Hurt 2000). Although Aly/REF has been shown to preferentially bind to spliced and not unspliced RNAs, there is evidence that Aly/REF mediates the nuclear export mRNAs regardless of whether they once contained an intron (Luo and Reed 1999; Rodrigues et al. 2001). Our chromatin immunoprecipitation experiments, which provide a snapshot of the in vivo association of Yral with PMA1 and GAL10, two genes that do not contain introns, are in agreement with Yral being a general export factor. Furthermore, Yral has been shown to interact directly with the mRNA export factor Mex67, which localizes primarily to nuclear pores, suggesting that Yra1 can function to bridge the formation of the RNP with the actual translocation machinery (Sträßer and Hurt 2000). If this is indeed the case, our results imply that full
Figure 7. Model for cotranscriptional recruitment of mRNA export factors. Npl3 is recruited to the transcription machinery perhaps by Pol II in the preinitiation complex and/or elongating Pol II and then transferred to the nascent transcript. Further recruitment of $\mathrm{Npl} 3$ continues as elongation proceeds. CBC is also recruited to the nascent transcript possibly dependent on Npl3. Yral associates with the nascent RNA at a late step of transcription. Other RNA-binding proteins are indicated (black). Cotranscriptional recruitment of these factors promotes efficient export of the RNP.
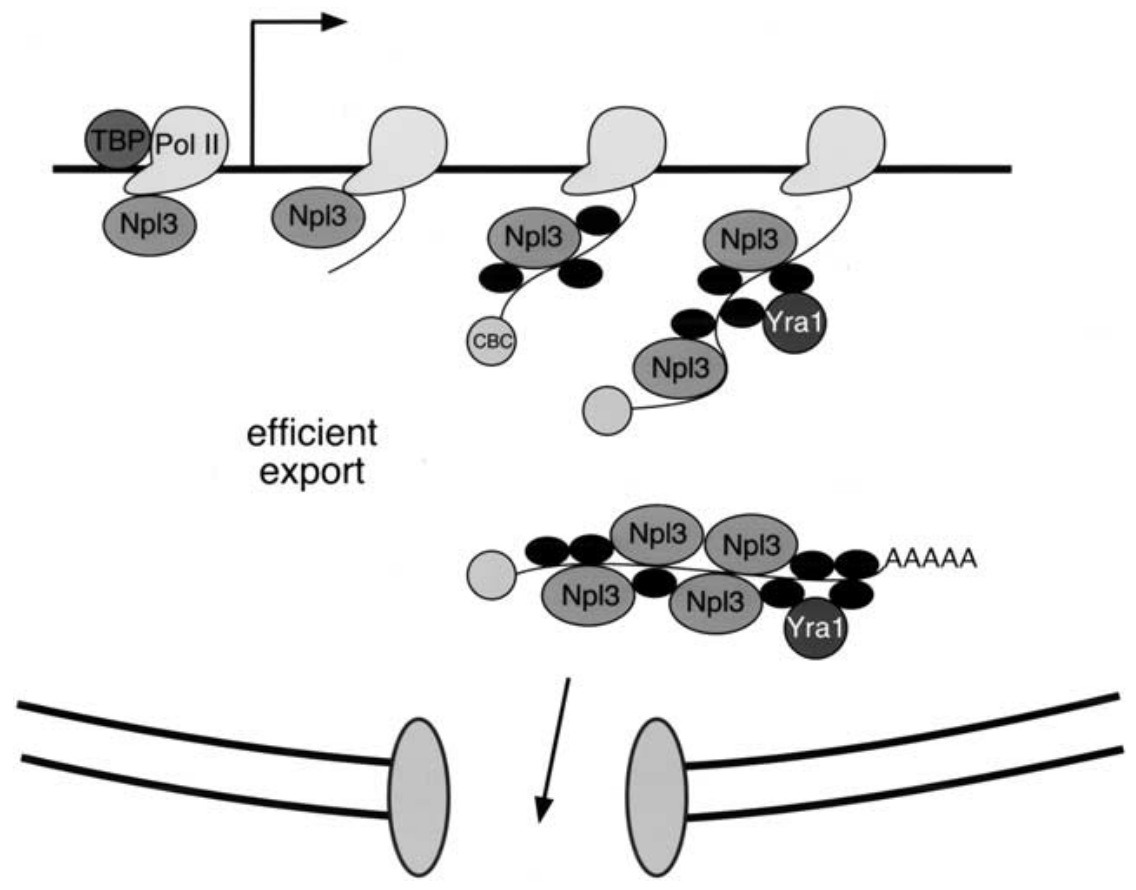
maturation of the RNP can occur cotranscriptionally. Mounting evidence for cotranscriptional recruitment of multiple factors involved in pre-mRNA processing supports this hypothesis.

\section{Transcription coordinates assembly of the export-competent RNP}

$N P L 3$ lies at the center of an increasingly complex network of genes. One such gene is HRP1, which encodes another abundant hnRNP (Henry et al. 1996). Hrp1 is involved in $3^{\prime}$ processing and nonsense mediated decay and recently has been shown to be associated with transcribed genes similar to the pattern exhibited by $\mathrm{Npl3}$ (Kessler et al. 1997; Gonzalez et al. 2000; Komarnitsky et al. 2000). Like Npl3, Hrp1 shuttles between the nucleus and cytoplasm dependent on ongoing transcription (Shen et al. 1998). Furthermore, NPL3 genetically and physically interacts with the CBC gene CBP8O in that combinations of mutant alleles of $n p l 3$ and $c b p 80$ display synthetic lethal interactions, and $\mathrm{Npl3}$ is strongly associated with the $\mathrm{CBC}$ proteins $\mathrm{Cbp} 80$ and $\mathrm{Cbp} 20$ in an RNA-dependent manner (Shen et al. 2000). We have found that $C B P 80$ is not required for $\mathrm{Npl} 3$ recruitment to transcribing genes (E. Lei and P. Silver, unpubl.). Although CBC has not been shown to bind to RNA cotranscriptionally in yeast, this result raises the possibility that $\mathrm{Npl3}$ promotes $\mathrm{CBC}$ recruitment to nascent RNAs.

In combination with previously published reports, our data show that mRNA export and processing factors are cotranscriptionally recruited to perform their function in maturation of the RNA for nuclear export. This mechanism may explain early observations in which mRNA export in Xenopus was stimulated by injection of promoter DNA containing an intact consensus TATA-box (de la Pena and Zasloff 1987). Additionally, identification of $p$ tr6 $6^{+}$, which encodes a putative TBP-associated factor (TAF), in a screen for mRNA export genes in $S$. pombe suggests that additional transcription factors may be involved in this process (Shibuya et al. 1999). In sum, we have shown that chromatin immunoprecipitation is a powerful technique that can be used to order the steps of recruitment of proteins to RNA, an outstanding question in the field of mRNA processing and export. Our results suggest that $\mathrm{Npl3}$ recruitment is an early event, possibly occurring at transcription initiation and that Yral recruitment is a later event, perhaps signaling the complete maturation of the RNP for export (Fig. 7). Future studies will further understanding of RNP assembly.

\section{Materials and methods}

\section{Yeast strains and genetic manipulations}

Standard yeast methods and media were utilized (Guthrie and Fink 1991). Strains used in this study: FY23/PSY580 MATa

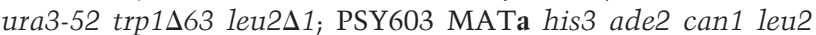
lys1 ura3 ade8; PSY 1031 MAT $\alpha$ np13-27 ura3-52 leu2-3,112 his3 lys1-1 trp1-1 ade2-1 ade8 can1-100; PSY 1032 MATa npl327 ura3-52 leu2-3,112 his3 lys1-1 ade2-1 ade8 can1-100; PSY 1698 MAT $\alpha$ npl3-27 spt15-ts1 ura3-52 leu2-3,112 his3 lys1-1 ade2-1 ade8 can1-100; PSY 1699 MATa npl3-27 spt15-ts1 ade2-1 can1-100 his3 leu2-3,112 lys1-1 ura3-52 ade8; PSY 1702 MAT $\alpha$ spt15-ts1 ade2-1 ura3-52 leu2-3,112 his3 lys1-1 trp1-1 ade8 can1-100; PSY 1703 MAT $\alpha$ spt15-ts1 ade2-1 can1-100 his3 leu2-3,112 lys1-1 ura3-52 ade8; YRA1-MYC is identical to YRA1 shuffle MATa ade2 his3 leu2 trp1 ura3 yra1::HIS3 (Sträßer and Hurt 2000) but contains the plasmid pNOPMYCA1L-YRA1, which was constructed by cloning the entire ORF of YRA1 from pNOPPATA1L-YRA1 into the PstI site of pNOPMYCA1L (K. Straesser and E. Hurt, unpubl.). Strains were provided generously by F. Winston, Harvard Medical School (spt15-328, spt15-341), R. Young, Whitehead Institute for Biomedical Research (rpb1-1, CTD truncations), and E. Hurt, Biochemie Zentrum Heidelberg (YRA1-MYC).

Indirect immunofluorescence and in situ $\operatorname{poly}(A)^{+}$ RNA hybridization

These procedures were performed as described previously (Krebber et al. 1999).

\section{Generation of npl3-27 ts ${ }^{-}$library}

The integrated npl3-27 strains of both mating types, PSY1031 and 1032 , were used to generate $t s^{-}$mutants using a modified protocol as described (Lawrence 1991). The strains were grown to a density of $6 \times 10^{7}$ cells $/ \mathrm{mL}$ in YPD and were collected by centrifugation and resuspended in $5 \mathrm{~mL} 0.1 \mathrm{M}$ sodium phosphate at $\mathrm{pH}$ 7.0. Cells were mutagenized with $130 \mu \mathrm{L}$ ethyl methanesulfonate (EMS) to a killing rate of $50 \%$. Cells were incubated for $30 \mathrm{~min}$ at $30^{\circ} \mathrm{C}$ on a roller drum. The mutagenesis was stopped by the addition of $1 \mathrm{~mL}$ of $10 \%(\mathrm{w} / \mathrm{v})$ sodium thiosulfate, and the cells were collected by centrifugation, washed in $5 \mathrm{~mL} \mathrm{H} \mathrm{H}_{2} \mathrm{O}$ and resuspended in $1 \mathrm{~mL} \mathrm{H}_{2} \mathrm{O}$. Dilutions were plated on YPD plates to obtain $\sim 300$ cells per plate. After $5 \mathrm{~d}$ of growth at $25^{\circ} \mathrm{C}$, colonies were replica plated to YPD and incubated at $37^{\circ} \mathrm{C}$ for $5 \mathrm{~d}$. Four hundred and fifteen colonies that did not grow at $37^{\circ} \mathrm{C}$ were selected for the npl3-27 ts $\mathrm{s}^{-}$library.

\section{Isolation of npl3-27 export mutants}

The collection of $415 \mathrm{npl3-27} \mathrm{ts}^{-}$mutants was analyzed for localization of Npl3-27 by indirect immunofluorescence after a shift to $37^{\circ} \mathrm{C}$ for $30 \mathrm{~min}$ for mutants ts $300-415$ and $4 \mathrm{~h}$ for mutants ts1-400. Mutants that displayed $>20 \%$ of cells with nuclear accumulation of Npl3-27 were backcrossed to a parental np13-27 strain to determine if the $t s^{-}$mutation was recessive. The resulting diploids were sporulated and analyzed for the presence of a single $t s^{-}$mutation. $t s^{-}$spores were compared against $\mathrm{Ts}^{+}$spores using indirect immunofluorescence to verify that accumulation of Npl3-27 was linked to the $t s^{-}$mutation. Each strain was backcrossed to the parent npl3-27 strain two more times to remove undesired mutations resulting from the mutagenesis procedure. Mutations were cloned by complementation of the $t s^{-}$phenotype by transformation with a CEN URA3 library (Rose et al. 1987).

\section{Northern analysis}

Determination of poly $(A)^{+}$RNA levels Fifty $\mathrm{mL}$ of cells were grown to $\log$ phase $\left(1 \times 10^{7}\right.$ cells $\left./ \mathrm{mL}\right)$ at $25^{\circ} \mathrm{C}$ and half the culture was shifted to $37^{\circ} \mathrm{C}$ for $1 \mathrm{~h}$. Total RNA was isolated by the hot acid phenol method, and $2 \mu \mathrm{g}$ of total RNA was hybridized to a nitrocellulose membrane by slot blot hybridization and 
probed as described previously (Thompson and Young 1995). The radiolabeled poly dT probe was produced as described previously (Kuldell and Buratowski 1997). Signal was detected and quantitated by PhosphorImager (Molecular Dynamics).

Northern blotting Fifteen $\mu$ g of total RNA were separated by agarose gel electrophoresis and transferred to a Hybond $\mathrm{N}^{+}$ membrane (Amersham Pharmacia) by vacuum transfer in 20x SSC. A ${ }^{32}$ P-labeled 300-bp specific probe for ACT1 was labeled by random priming and hybridized to the membrane in hybridization buffer $(50 \mathrm{mM}$ PIPES at $\mathrm{pH} 7,100 \mathrm{mM} \mathrm{NaCl}, 50 \mathrm{mM}$ sodium phosphate at pH 6.9, $1 \mathrm{mM}$ EDTA, $5 \%$ SDS, $60 \mu \mathrm{g} / \mathrm{mL}$ sheared salmon sperm DNA) overnight at $65^{\circ} \mathrm{C}$ and washed three times in $0.5 \times \mathrm{SSC}+5 \%$ SDS at $65^{\circ} \mathrm{C}$ for $15 \mathrm{~min}$. Signal was quantitated by PhosphorImager.

\section{Chromatin immunoprecipitation}

Chromatin IPs were performed essentially as described (Dudley et al. 1999; Kuras and Struhl 1999). Briefly, $400 \mathrm{~mL}$ of cells were grown to early log phase $\left(\sim 1 \times 10^{7}\right.$ cells $\left./ \mathrm{mL}\right)$ at $30^{\circ} \mathrm{C}$ in YPD or YP containing $2 \%$ raffinose. For galactose induction, galactose was added to raffinose cultures to a final concentration of $2 \%$ and cultures were induced for $20 \mathrm{~min}$. Formaldehyde was added to a final concentration of $1 \%$ and cells were incubated at room temperature (RT) for $25 \mathrm{~min}$. Glycine was added to a final concentration of $360 \mathrm{mM}$. Cells were washed twice in $1 \times$ TBS and lysed with glass beads in breaking buffer $(0.1 \mathrm{M}$ Tris $\mathrm{pH}$ at 8.0 , $20 \%$ glycerol, $1 \mathrm{mM}$ PMSF) using two $30 \mathrm{sec}$ pulses at speed 6.5 $\mathrm{m} / \mathrm{sec}$ in a vortexer. Cross-linked chromatin was collected by centrifugation at 14,000 rpm for $1 \mathrm{~min}$, and pellets were washed twice in FA buffer (50 mM HEPES-KOH at $\mathrm{pH} 7.5,150 \mathrm{mM}$ $\mathrm{NaCl}, 1 \mathrm{mM}$ EDTA, $1 \%$ Triton $\mathrm{X}-100,0.1 \%$ DOC) and resuspended in $1.5 \mathrm{~mL}$ FA buffer. Cells were sonicated until DNA was of $200 \mathrm{bp}$ average size. Soluble chromatin was separated from insoluble material by centrifugation at 14,000 rpm for 10 min and adjusted to $8 \mathrm{~mL}$ with FA buffer. Chromatin was stored in $800 \mu \mathrm{L}$ aliquots at $-80^{\circ} \mathrm{C}$.

Immunoprecipitations were performed as described (Kuras and Struhl 1999). For $\alpha$-TBP, $8 \mu \mathrm{L}$ of antibody was coupled to protein A-sepharose beads. For $\alpha$-Npl3, $25 \mu \mathrm{L}$ of antibody was coupled to fixed Staphylococcus aureus bacteria. For $\alpha$-myc, 1 $\mu \mathrm{L}$ of 9E11 antibody was coupled to fixed S. aureus. Input and immunoprecipitated DNA was subjected to quantitative PCR as described (Komarnitsky et al. 2000) except $0.15 \mathrm{mCi} / \mathrm{mL}$ $\left[\alpha-{ }^{33} \mathrm{P}\right]$ dATP was used. PCR products were separated on an $8 \%$ TBE polyacrylamide gel and quantitated by PhosphorImager. A standard curve of six twofold serial dilutions of input in the linear range of PCR was obtained. Four twofold serial dilutions of immunoprecipitate were plotted against the standard curve to determine the percentage of input DNA in each immunoprecipitate. Experiments were performed at least twice, and each experiment yielded similar results.

The sequence of PMA1 primers are the same as described (Komarnitsky et al. 2000). The sequence of GAL10 primers used are GAL10-1: GAGCCCCATTATCTTAGCC and TTACTGC CAATTTTTCCTCT; GAL10-2: TTAAACTTCTTTGCGTC CATCC and TGCTTGGTCAAGACCTCTAACC; GAL10-3: TGTCGTGAGTGGAACTTGGGTT and GCATATCTTCAG CGGAAAATCTGGC; GAL10-4: TGTCAAGGCTTTTCATC CCGATTC and TTGGACCCGTAAGTTTCACCGT; Intergenic region: GAAAAAGTGGGATTCTGCCTGTGG and GT TTGCCACAGCGACAGAAGTATAACC.; tRNA $_{\text {GUC: }}$ STR2963 CACCACAAATGGAAAAGCGACTTTC and STR2964 CCT GTTATTTCCAAAGAACTGGGTTC; tRNA $_{\text {CUU }}$ STR2967 GCACTAGTTGATTCTTGTTCCAACAG and STR2968 CC
GTTTTTCCCCAGAGCACTTTTA (L. Kuras and K. Struhl, unpubl.).

\section{Immunoprecipitation}

Immunoprecipitations were performed essentially as described (Hartzog et al. 1998). Cells $\left(50 \mathrm{~mL}\right.$ ) were grown in YPD at $30^{\circ} \mathrm{C}$ to mid log phase $\left(2.5 \times 10^{7}\right.$ cells $\left./ \mathrm{mL}\right)$ and lysed with glass beads by vortexing at speed 6.5 for $30 \mathrm{sec}$ in lysis buffer $(25 \mathrm{mM}$ $\mathrm{NaPO}_{4}$ at $\mathrm{pH} 6.8,0.1 \mathrm{M} \mathrm{KOAc}, 2 \mathrm{mM} \mathrm{MgOAc}, 10 \%$ glycerol, 1 $\mathrm{mM}$ PMSF, $3 \mathrm{ng} / \mathrm{mL}$ pepstatin, $3 \mathrm{ng} / \mathrm{mL}$ leupeptin, $3 \mathrm{ng} / \mathrm{mL}$ aprotinin, $3 \mathrm{ng} / \mathrm{mL}$ chymostatin, $0.2 \mathrm{mM} \mathrm{Na}_{3} \mathrm{VO}_{4}, 5 \mathrm{mM}$ $\beta$-glycerophosphate, $1 \mathrm{mM} \mathrm{NaF})$. Total lysate $(1 \mathrm{mg})$ was added to IP/wash buffer (lysis buffer with $0.5 \mathrm{M} \mathrm{NH}_{4} \mathrm{OAc}, 0.1 \%$ Tween 20) to a final volume of $900 \mu \mathrm{L}$. Lysates were precleared with $3 \mu \mathrm{L} \alpha$-Npl3 preimmune serum and $100 \mu \mathrm{L}$ S. aureus in $\mathrm{IP} /$ wash buffer for $1 \mathrm{~h}$. Fourteen $\mu \mathrm{L} \alpha-\mathrm{Npl} 3$ was added to lysates and incubated overnight. One hundred $\mu \mathrm{L} S$. aureus was added and incubated for $1 \mathrm{~h}$, and immune complexes were washed five times in $1 \mathrm{~mL} \mathrm{IP} /$ wash buffer and raised in $20 \mu \mathrm{L} \mathrm{IP} /$ wash buffer. Samples containing RNase A were at a concentration of $50 \mu \mathrm{g} /$ $\mathrm{mL}$. Samples were incubated for $20 \mathrm{~min}$ at RT then washed once with $1 \mathrm{~mL}$ of IP/wash buffer and resuspended in sample loading buffer. Samples were run on a 7\% SDS-PAGE gel, transferred to nitrocellulose in $10 \mathrm{mM}$ CAPS (pH 11), $1 \% \mathrm{MeOH}$ and Western blotted with 8WG16 (1:500) and $\alpha$-Npl3 $(1: 10,000)$.

\section{Acknowledgments}

We are grateful to P. Komarnitsky for help with the chromatin IPs and C. Kaplan for helpful discussions. We would also like to thank K. Straesser and E. Hurt for the YRA1-MYC strain, S. Buratowski for $\alpha$-TBP, F. Winston for primers and 8WG16, B. Spiegelman for H5, R. Young for 9E11, K. Struhl for primers, and B. Srivastava for sequencing. We thank S. Buratowski, C. Kaplan, A. Hatton, T. Moy, and T. Zimmermann for comments on the manuscript. E.P.L. was supported by grants from the NCI and the Ryan Foundation. H.K. was supported by a fellowship from the Deutsche Forschungsgemeinschaft. This work was supported by grants from the NIH to P.A.S.

The publication costs of this article were defrayed in part by payment of page charges. This article must therefore be hereby marked "advertisement" in accordance with 18 USC section 1734 solely to indicate this fact.

\section{References}

Alzhanova-Ericsson, A.T., Sun, X., Visa, N., Kiseleva, E., Wurtz, T., and Daneholt, B. 1996. A protein of the SR family of splicing factors binds extensively to exonic Balbiani ring premRNA and accompanies the RNA from the gene to the nuclear pore. Genes \& Dev. 10: 2881-2893.

Amberg, D.C., Goldstein, A.L., and Cole, C.N. 1992. Isolation and characterization of RAT1: An essential gene of Saccharomyces cerevisiae required for the efficient nucleocytoplasmic trafficking of mRNA. Genes \& Dev. 6: 1173-1189.

Arndt, K.M., Ricupero-Hovasse, S., and Winston, F. 1995. TBP mutants defective in activated transcription in vivo. $E M B O$ J. 14: 1490-1497.

Bachi, A., Braun, I.C., Rodrigues, J.P., Pante, N., Ribbeck, K., von Kobbe, C., Kutay, U., Wilm, M., Gorlich, D., CarmoFonseca, M., et al. 2000. The C-terminal domain of TAP interacts with the nuclear pore complex and promotes export of specific CTE-bearing RNA substrates. RNA 6: 136-158. 
Bossie, M.A., DeHoratius, C., Barcelo, G., and Silver, P. 1992. A mutant nuclear protein with similarity to RNA binding proteins interferes with nuclear import in yeast. Mol. Biol. Cell 3: 875-893.

Cho, E.J., Takagi, T., Moore, C.R., and Buratowski, S. 1997. mRNA capping enzyme is recruited to the transcription complex by phosphorylation of the RNA polymerase II carboxy-terminal domain. Genes \& Dev. 11: 3319-3326.

Cormack, B.P. and Struhl, K. 1992. The TATA-binding protein is required for transcription by all three nuclear RNA polymerases in yeast cells. Cell 69: 685-696.

Dantonel, J.C., Murthy, K.G., Manley, J.L., and Tora, L. 1997. Transcription factor TFIID recruits factor CPSF for formation of 3' end of mRNA. Nature 389: 399-402.

de la Pena, P. and Zasloff, M. 1987. Enhancement of mRNA nuclear transport by promoter elements. Cell 50: 613-619.

Dudley, A.M., Rougeulle, C., and Winston, F. 1999. The Spt components of SAGA facilitate TBP binding to a promoter at a post-activator-binding step in vivo. Genes \& Dev. 13: 2940-2945.

Fabre, E. and Hurt, E. 1997. Yeast genetics to dissect the nuclear pore complex and nucleocytoplasmic trafficking. Annu. Rev. Genet. 31: 277-313.

Flach, J., Bossie, M., Vogel, J., Corbett, A., Jinks, T., Willins, D.A., and Silver, P.A. 1994. A yeast RNA-binding protein shuttles between the nucleus and the cytoplasm. Mol. Cell. Biol. 14: 8399-8407.

Gilbert, W., Siebel, C.W. and Guthrie, C. 2001. Phosphorylation by Skylp promotes Npl3p shuttling and mRNA dissociation. RNA 7: 302-313.

Gonzalez, C.I., Ruiz-Echevarria, M.J., Vasudevan, S., Henry, M.F., and Peltz, S.W. 2000. The yeast hnRNP-like protein Hrp1/Nab4 marks a transcript for nonsense-mediated mRNA decay. Mol. Cell 5: 489-499.

Gruter, P., Tabernero, C., von Kobbe, C., Schmitt, C., Saavedra, C., Bachi, A., Wilm, M., Felber, B.K., and Izaurralde, E. 1998. TAP, the human homolog of Mex67p, mediates CTE-dependent RNA export from the nucleus. Mol. Cell 1: 649-659.

Guthrie, C. and Fink, G.R. 1991. Guide to yeast genetics and molecular biology. Methods Enzymol. 194: 1-863.

Hartzog, G.A., Wada, T., Handa, H., and Winston, F. 1998. Evidence that Spt4, Spt5, and Spt6 control transcription elongation by RNA polymerase II in Saccharomyces cerevisiae. Genes \& Dev. 12: 357-369.

Henry, M., Borland, C.Z., Bossie, M., and Silver, P.A. 1996. Potential RNA binding proteins in Saccharomyces cerevisiae identified as suppressors of temperature-sensitive mutations in NPL3. Genetics 142: 103-115.

Hirose, Y. and Manley, J.L. 2000. RNA polymerase II and the integration of nuclear events. Genes \& Dev. 14: 1415-1429.

Hodge, C.A., Colot, H.V., Stafford, P., and Cole, C.N. 1999. Rat8p/Dbp5p is a shuttling transport factor that interacts with Rat7p/Nup159p and Glelp and suppresses the mRNA export defect of xpo1-1 cells. EMBO J. 18: 5778-5788.

Jankowsky, E., Gross, C.H., Shuman, S. and Pyle, A.M. 2001. Active disruption of an RNA-protein interaction by a DExH/D RNA helicase. Science 291: 121-125.

Jove, R. and Manley, J.L. 1984. In vitro transcription from the adenovirus 2 major late promoter utilizing templates truncated at promoter-proximal sites. J. Biol. Chem. 259: 85138521.

Kadowaki, T., Hitomi, M., Chen, S. and Tartakoff, A.M. 1994. Nuclear mRNA accumulation causes nucleolar fragmentation in yeast mtr2 mutant. Mol. Biol. Cell 5: 1253-1263.

Kang, Y. and Cullen, B.R. 1999. The human Tap protein is a nuclear mRNA export factor that contains novel RNA-bind- ing and nucleocytoplasmic transport sequences. Genes \& Dev. 13: 1126-1139.

Katahira, J., Sträßer, K., Podtelejnikov, A., Mann, M., Jung, J.U., and Hurt, E. 1999. The Mex67p-mediated nuclear mRNA export pathway is conserved from yeast to human. EMBO $J$. 18: 2593-2609.

Kataoka, N., Yong, J., Kim, V.N., Velazquez, F., Perkinson, R.A., Wang, F. and Dreyfuss, G. 2000. Pre-mRNA splicing imprints mRNA in the nucleus with a novel RNA-binding protein that persists in the cytoplasm. Mol. Cell 6: 673-682.

Kessler, M.M., Henry, M.F., Shen, E., Zhao, J., Gross, S., Silver, P.A., and Moore, C.L. 1997. Hrp1, a sequence-specific RNAbinding protein that shuttles between the nucleus and the cytoplasm, is required for mRNA 3'-end formation in yeast. Genes \& Dev. 11: 2545-2556.

Komarnitsky, P., Cho, E.J., and Buratowski, S. 2000. Different phosphorylated forms of RNA polymerase II and associated mRNA processing factors during transcription. Genes \& Dev. 14: 2452-2460.

Krebber, H., Taura, T., Lee, M.S. and Silver, P.A. 1999. Uncoupling of the hnRNP Npl3p from mRNAs during the stressinduced block in mRNA export. Genes \& Dev. 13: 19942004.

Kuldell, N.H. and Buratowski, S. 1997. Genetic analysis of the large subunit of yeast transcription factor IIE reveals two regions with distinct functions. Mol. Cell. Biol. 17: 52885298.

Kuras, L. and Struhl, K. 1999. Binding of TBP to promoters in vivo is stimulated by activators and requires Pol II holoenzyme. Nature 399: 609-613.

Lawrence, C.W. 1991. Classical mutagenesis techniques. Methods Enzymol. 194: 273-281.

Le Hir, H., Izaurralde, E., Maquat, L.E. and Moore, M.J. 2000. The spliceosome deposits multiple proteins 20-24 nucleotides upstream of mRNA exon-exon junctions. EMBO $J$. 19: 6860-6869.

Lee, M.S., Henry, M., and Silver, P.A. 1996. A protein that shuttles between the nucleus and the cytoplasm is an important mediator of RNA export. Genes \& Dev. 10: 12331246.

Luo, M.J. and Reed, R. 1999. Splicing is required for rapid and efficient mRNA export in metazoans. Proc. Natl. Acad. Sci. 96: $14937-14942$.

McCracken, S., Fong, N., Yankulov, K., Ballantyne, S., Pan, G., Greenblatt, J., Patterson, S.D., Wickens, M., and Bentley, D.L. 1997. The C-terminal domain of RNA polymerase II couples mRNA processing to transcription. Nature 385: 357-361.

Mortillaro, M.J., Blencowe, B.J., Wei, X., Nakayasu, H., Du, L., Warren, S.L., Sharp, P.A., and Berezney, R. 1996. A hyperphosphorylated form of the large subunit of RNA polymerase II is associated with splicing complexes and the nuclear matrix. Proc. Nat1. Acad. Sci. 93: 8253-8257.

Orlando, V., Strutt, H., and Paro, R. 1997. Analysis of chromatin structure by in vivo formaldehyde cross-linking. Methods 11: 205-214.

Pemberton, L.F., Rosenblum, J.S., and Blobel, G. 1997. A distinct and parallel pathway for the nuclear import of an mRNA-binding protein. J. Cell. Biol. 139: 1645-1653.

Rasmussen, E.B. and Lis, J.T. 1993. In vivo transcriptional pausing and cap formation on three Drosophila heat shock genes. Proc. Natl. Acad. Sci. 90: 7923-7927.

Rodrigues, J.P., Rode, M., Gatfield, D., Blencowe, B., CarmoFonseca, M., and Izaurralde, E. 2001. REF proteins mediate the export of spliced and unspliced mRNAs from the nucleus. Proc. Natl. Acad. Sci. 98: 1030-1035. 
Lei et al.

Rose, M.D., Novick, P., Thomas, J.H., Botstein, D., and Fink, G.R. 1987. A Saccharomyces cerevisiae genomic plasmid bank based on a centromere-containing shuttle vector. Gene 60: 237-243.

Salditt-Georgieff, M., Harpold, M., Chen-Kiang, S., and Darnell, J.E., Jr. 1980. The addition of $5{ }^{\prime}$ cap structures occurs early in hnRNA synthesis and prematurely terminated molecules are capped. Cell 19: 69-78.

Santos-Rosa, H., Moreno, H., Simos, G., Segref, A., Fahrenkrog, B., Panté, N., and Hurt, E. 1998. Nuclear mRNA export requires complex formation between Mex67p and Mtr2p at the nuclear pores. Mol. Cell. Biol. 18: 6826-6838.

Schroeder, S.C., Schwer, B., Shuman, S., and Bentley, D. 2000. Dynamic association of capping enzymes with transcribing RNA polymerase II. Genes \& Dev. 14: 2435-2440.

Senger, B., Simos, G., Bischoff, F.R., Podtelejnikov, A., Mann, M., and Hurt, E. 1998. Mtr10p functions as a nuclear import receptor for the mRNA-binding protein Npl3p. EMBO I. 17: 2196-2207.

Shen, E.C., Henry, M.F., Weiss, V.H., Valentini, S.R., Silver, P.A., and Lee, M.S. 1998. Arginine methylation facilitates the nuclear export of hnRNP proteins. Genes \& Dev. 12: 679-691.

Shen, E.C., Stage-Zimmermann, T., Chui, P., and Silver, P.A. 2000. The yeast mRNA-binding protein Npl3p interacts with the cap-binding complex. J. Biol. Chem. 275: 2371823724.

Shibuya, T., Tsuneyoshi, S., Azad, A.K., Urushiyama, S., Ohshima, Y., and Tani, T. 1999. Characterization of the ptr6(+) gene in fission yeast: A possible involvement of a transcriptional coactivator TAF in nucleocytoplasmic transport of mRNA. Genetics 152: 869-880.

Singleton, D.R., Chen, S., Hitomi, M., Kumagai, C., and Tartakoff, A.M. 1995. A yeast protein that bidirectionally affects nucleocytoplasmic transport. J. Cell. Sci. 108: 265-272.

Snay-Hodge, C.A., Colot, H.V., Goldstein, A.L., and Cole, C.N. 1998. Dbp5p/Rat8p is a yeast nuclear pore-associated DEAD-box protein essential for RNA export. EMBO $J$. 17: 2663-2676.

Strahm, Y., Fahrenkrog, B., Zenklusen, D., Rychner, E., Kantor, J., Rosbash, M., and Stutz, F. 1999. The RNA export factor Glelp is located on the cytoplasmic fibrils of the NPC and physically interacts with the FG-nucleoporin Riplp, the DEAD-box protein Rat8p/Dbp5p and a new protein Ymr255p. EMBO J. 18: 5761-5777.

Sträßer, K. and Hurt, E. 2000. Yralp, a conserved nuclear RNAbinding protein, interacts directly with Mex67p and is required for mRNA export. EMBO T. 19: 410-420.

Sträßer, K., Bassler, J., and Hurt, E. 2000. Binding of the Mex67p/Mtr2p heterodimer to FXFG, GLFG, and FG repeat nucleoporins is essential for nuclear mRNA export. J. Cell. Biol. 150: 695-706.

Sun, X., Alzhanova-Ericsson, A.T., Visa, N., Aissouni, Y., Zhao, J., and Daneholt, B. 1998. The hrp23 protein in the balbiani ring pre-mRNP particles is released just before or at the binding of the particles to the nuclear pore complex. J. Cell. Biol. 142: 1181-1193.

Thompson, C.M. and Young, R.A. 1995. General requirement for RNA polymerase II holoenzymes in vivo. Proc. Natl. Acad. Sci. 92: 4587-4590.

Visa, N., Alzhanova-Ericsson, A.T., Sun, X., Kiseleva, E., Bjorkroth, B., Wurtz, T., and Daneholt, B. 1996a. A pre-mRNAbinding protein accompanies the RNA from the gene through the nuclear pores and into polysomes. Cell 84: 253 264.

Visa, N., Izaurralde, E., Ferreira, J., Daneholt, B., and Mattaj,
I.W. 1996b. A nuclear cap-binding complex binds Balbiani ring pre-mRNA cotranscriptionally and accompanies the ribonucleoprotein particle during nuclear export. I. Cell. Biol. 133: $5-14$.

Wilson, S.M., Datar, K.V., Paddy, M.R., Swedlow, J.R., and Swanson, M.S. 1994. Characterization of nuclear polyadenylated RNA-binding proteins in Saccharomyces cerevisiae. J. Cell. Biol. 127: 1173-1184.

Yuryev, A., Patturajan, M., Litingtung, Y., Joshi, R.V., Gentile, C., Gebara, M., and Corden, J.L. 1996. The C-terminal domain of the largest subunit of RNA polymerase II interacts with a novel set of serine/arginine-rich proteins. Proc. Nat1. Acad. Sci. 93: 6975-6980.

Zhou, Z., Luo, M.J., Straesser, K., Katahira, J., Hurt, E., and Reed, R. 2000. The protein Aly links pre-messenger-RNA splicing to nuclear export in metazoans. Nature 407: 401405. 


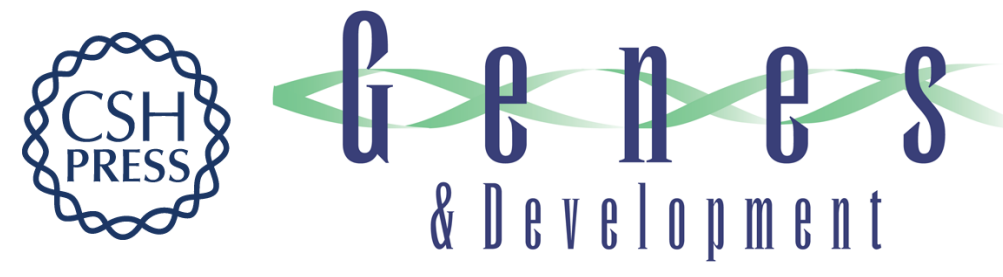

\section{Messenger RNAs are recruited for nuclear export during transcription}

Elissa P. Lei, Heike Krebber and Pamela A. Silver

Genes Dev. 2001, 15:

Access the most recent version at doi:10.1101/gad.892401

References This article cites 61 articles, 44 of which can be accessed free at: http://genesdev.cshlp.org/content/15/14/1771.full.html\#ref-list-1

License

Email Alerting Receive free email alerts when new articles cite this article - sign up in the box at the top Service right corner of the article or click here.

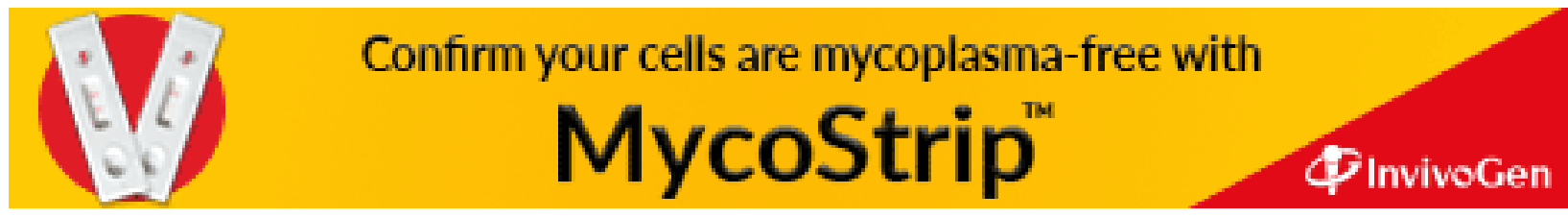

